\title{
Neighbours of a family with a disabled person
}

\section{KEYWORDS}

neighbours, disability

\begin{abstract}
Beata Górnicka, Neighbours of a family with a disabled person. Culture - Society - Education no. 1(19) 2021, Poznań 2021, pp. 51-60, Adam Mickiewicz University Press. ISSN 2300-0422. DOI 10.14746/kse.2021.19.4

Nowadays, social changes include the perception not only of disability itself, but also of a family with a disabled member. These changes concern the organisation of support for the family, which functions in the entire social ecosystem, including the closest social groups, e.g., the neighbourhood. Although this neighbourhood, which is also subject to changes, can become an invaluable source of support, unfortunately, it may also become an environment that contributes to the social exclusion of a family. In this paper, the author presents selected aspects of the co-existence of people with disabilities and their families with their neighbours. The paper used research on opinions about being the neighbour of a family with a disabled person, which included declarations of help or support really offered. The author asserts that a family with a disabled person can experience both positive and negative attitudes and behaviours from neighbours.
\end{abstract}

\section{Introduction}

In our times, human life goes on against the background of many social-cultural and economic changes that are often unpredictable and for a long time have made

* ORCID https://orcid.org/0000-0001-5699-2203. 
social reality increasingly complex. Reality, which is still defined as postmodernity and causes many changes and threats, does not overlook anyone, including a family affected bye disability, irrespective of the family member whom it affects directly (child or parent), or regardless of the moment at which it emerges. Changes manifest themselves both in terms of the perception of disability itself and of the family with a disabled person and the organisation of support for such a family. These changes concern how the family functions within the entire social ecosystem, including the nearest social groups, such as the neighbourhood. Neighbourhoods are also subject to transformation and may constitute an invaluable source of support for a family with a disabled person. Unfortunately, however, the neighbourhood may also become an environment contributing to social exclusion.

In this paper, I attempt to outline selected aspects of the co-existence of disabled persons and their families in the space of neighbourly life by showing selected results of research concerning social opinions on the neighbourhood of a family with a disabled person, declarations or actual help and support provided. This may induce the reader to consider important problems that are a reflection of modern times, particularly because everyone is a neighbour, whose environment may include a family with a disability problem.

\section{About modern faces of the neighbourhood}

When reflecting on neighbourhood, it is impossible to ignore references to the traditional approach to the local environment from the perspective of social pedagogy, where this environment is defined as a 'community of people inhabiting a limited and relatively isolated territory, possessing and appreciating a common tradition, common values and symbols and service and cultural institutions, being aware of their unity and distinctness and ready for community action and living in a sense of belonging and internal safety' (Pilch, Lepalczyk, 1995: 157). This concept gradually changes its semantic scope along with the progress of democratisation and globalisation. In the opinion of Wiesław Theiss, the local environment means a 'community that lives within a small space (from a small village to a geographical region) and its members are focused around approved values, goals or interests. The things that are common and unite members of the local environment include culture and its heritage (tradition, identity, belonging, loyalty to the place or land), forms of social life (neighbourhood, local solidarity, local patriotism, common biography), the local natural environment (nature, geographical conditions, landscape)' (Theiss, 2001: 11-12). Many authors stress that in modern times, along 
with numerous civilisational \& social changes, autonomisation and individualisation and the weakening of strict social control, 'social bonds are superficial, factual and anonymous, as a result of which the sense of belonging to the given place becomes weaker, the role of authorities and the impact of family on private life decrease, and neighbourly relations disappear, too' (Czarnecki, 2012: 404).

Burdened with work and trying to keep up with daily challenges, people increasingly often retreat into their own homes, which undoubtedly leads to weaker neighbourly relations and renders interpersonal contact more superficial. Locked up in our important everyday matters, we do not notice others around us. Although, as Alina Szczurek-Boruta stresses, the postmodern concentration of the human being 'on himself and his own goals is dominant in modern times, it does not exclude the awareness of other persons' needs and actions for the common good. It is unjustified to assume that individualistic values are causally related to egoism, competition and isolation from Others' (2016: 64). This is suggested by data obtained during surveys conducted by CBOS in 2017.

The report entitled Polacy o relacjach z sasiadami (Poles on relations with neighbours) (CBOS 2017) shows that Poles' declarations regarding their relations with neighbours have not changed significantly during the last five years. Poles maintain occasional and fairly conventional neighbourly relations. Neighbourly relations are limited to courteous contacts (such as greeting neighbours upon meeting them), which is declared by $84 \%$ of respondents. Although they do not avoid contacts with neighbours (89\%), a majority of respondents (65\%) admit that they maintain distance in their neighbourly relations. Only every tenth respondent (10\%) says that they avoid any contact. In spite of this, the mutual provision of small neighbourly services (72\%), such as lending an item or taking care of a child, becomes quite common, but a large group of respondents (64\%) admit that they maintain such close relations only with few neighbours. The survey data show that every third respondent maintains social contacts with neighbours, which includes mutual visits, participation in family ceremonies (e.g., name-day parties), but these relations are not very frequent (32\% say that they have at least one and a maximum of five such neighbours).

In the survey, consideration was also given to emerging neighbourly tensions and conflicts. It turns out that every tenth respondent (10\%) is in conflict with their neighbours. Although conflict situations are stated as being rare, their number has risen quite significantly in comparison to the survey conducted five years ago (an increase from 6\% to 10\%). Moreover, according to respondents' declarations, the circle of neighbours with whom Poles maintain conventional and beneficial relations becomes narrower.Moreover, an alternative report Badanie relacji 
sasiedzkich (An examination of neighbourly relations), prepared by Morizon (2017) in May 2017, provides data obtained in a group of 1,067 respondents from Poland presenting the degree of development of acquaintances with a neighbour, relations, trust, mutual favours and annoying behaviours. The results are similar to those obtained in CBOS and show that most respondents assess their relations with neighbours as good or neutral, with only $4 \%$ of respondents complaining about bad or very bad relations. According to the authors of the report, we value our privacy and prefer to maintain a safe distance, and small neighbourly favours are most often limited to accepting courier parcels during the neighbour's absence. We do not make attempts to get to know our neighbours better and we are not particularly interested in neighbourly initiatives or integrative meetings. The situation regarding relations between neighbours is spatially diversified. It transpires that 'inhabitants of the Opole Province get on particularly well with their neighbours $77 \%$ of these respondents assess their neighbourly relations as good or very good. In the Opole region, the distance between neighbours is smaller than in the rest of the country: every second respondent maintains social contacts. Things look much worse in the Podlasie Province, where only 2 out of 10 respondents admit they are friends with their neighbours. As many as $64 \%$ of respondents in Podlasie have had at least one argument with their neighbour. These conflicts seem to have weakened mutual trust: every second respondent is not willing to sit at one table with their neighbour' (Morizon, 2017).

Local environments, including neighbourly ones, become increasingly diversified, largely as a result of current social changes, and 'we can regard every environment as beneficial or harmful for individual development, depending on the evaluation criteria adopted' (Czarnecki, 2012: 404), which gains particular significance when we consider difficult life situations, and grappling with disability is certainly one of these.

\section{Disability in the social mirror}

Disability is currently perceived as an important social issue. According to WHO data, it affects every tenth person around the world. As a relatively common phenomenon knowing no temporal or spatial boundaries, disability affects people of different age from various social strata and with a different life potential or level of education or affluence. It is of interest to representatives of various academic fields, including sociologists, psychologists and particularly pedagogues. It is especially important that disabled persons are commonly considered to deserve full human 
rights: the right to life, the right to have a family, the right to social participation and, consequently, neighbourly participation.

Standing for something that makes it difficult or impossible or limits the human being's scope for independent action in personal and social roles due to the biopsychosocial health of the individual, disability does not ultimately define the human being. Even if it determines his/her biography to a lesser or greater extent, it does not deprive him/her of dignity and should never become a reason for exclusion. A disabled person and his/her whole family have every right to participate in social life and to create and use commonly available social goods. However, the actual situation of disabled persons and their families is determined to a large extent by the social perception of disability and social attitudes towards disabled persons and their families.

According to Hanna Zuraw, 'in the course of history, we can distinguish two main epochs in the development of societies' attitudes to disability. The first covered the pre-industrial and industrial era, and the second is formed by postindustrial times. In each of them, factors shaping social attitudes towards disability acted in a particular way' (Żuraw, 2016: 27). The authors tracking the evolution of the approach to disability point out the diversity of factors shaping social attitudes towards disabled persons, from their extermination up to the social approval of their participation in the mainstream of social life with the right to assume and fulfil various social roles. Żuraw stresses that in the times of post-modernism, 'certain phenomena become less transparent. The borders between the norm and difference become fluid. Certain dysfunctions seem to lose their derogatory implications. (...) Thanks to such things as the achievements of science - medicine, technology (biotechnology) or legal regulations, the human being is able to change himself/herself' (Żuraw, 2016: 38).

Changes in the approach to disability lead from its interpretation from the biological perspective (in which it constitutes an individual problem) to its perception from the social perspective, where it constitutes the problem for society as a whole, whose task is to protect and support its weaker members' (Kirenko, 2007: 5-6). The social model of disability assumes a certain approach to its issues, to rights of disabled persons or social attitudes towards them and their problems that 'express an inclination to establish interpersonal relations. This generates the need to shape proper social attitudes, i.e., those that will support inclusion on the one hand and the elimination of stereotypes, prejudices and discriminatory practices on the other' (Kazanowski, 2015: 34).

From the perspective of the reflections undertaken in this paper, it is worth stressing that the emergence of disability in the family usually causes numerous dif- 
ficulties in its functioning that may generate problems, including emotional problems, problems in partner relations, care and upbringing, livelihood, professional and social problems (Górnicka, 2012: 369-384). What are particularly significant are problems in social contacts, including neighbourly and social contacts, e.g., the rapture of neighbourly and friendly bonds and the limitation of social and cultural life, which intensifies the sense of loneliness and isolation and limits the satisfaction of family needs. In addition, experiencing negative social attitudes and a sense of stigmatisation and social exclusion, which, by becoming a reason for the sense of injustice and sometimes shame, may lead to the avoidance of social contacts and the limitation of contacts with the external environment. In this context, it is also important to notice the significance of negative or even only indifferent social attitudes that are still very often manifested even in the closest social environment, including the neighbourhood, in spite of the commonly declared full acceptance of disabled persons and their families. This is connected with the presence of stereotypes and behaviours indicating the discrimination of disabled persons.

However, it must be remembered that the personal experiences of able-bodied persons contacting disabled persons and their families, particularly in the situation of friendly approach based on understanding and empathy, indicate the uniqueness of the social bonds formed between those two groups, and the acceptance of disabled persons by the social environment (e.g., in the neighbourhood) to an increasing extent supports their universal development, the formation of their identity, its increasing autonomy and increasingly more independent functioning. Thus, it also helps to build a genuine community in the common space of co-being.

\section{A disabled person and his/her family in the neighbourly circle}

Issues regarding neighbourly contacts and the relations of disabled persons and their families are not raised frequently by authors; they tend to appear on the occasion of research on their life situation or life quality, problems in the functioning and social support of disabled persons and their families or research concerning social attitudes towards disabled persons. Most data that clearly portray the neighbourhood of families with the problem of disability are contained in reports and statements on research conducted by CBOS or other foundations and associations, usually with a local reach. There are also significant reports from the mass media; however, they usually show individual cases of neighbourly conflicts with negative implications or cover events in which disabled persons and their families participate (e.g., local Neighbour Days that have been organised for a few years). 
Indicating the above gap and in consideration of the limited scope of this paper, we will refer in a brief and generalised manner to some conclusions from selected studies presenting social opinions on the issues brought up here. For example, according to the report Postawy wobec osób niepetnosprawnych. Komunikat $z$ badan CBOS (Attitudes to disabled people) (CBOS, 2007) concerning attitudes towards disabled persons, $45 \%$ of respondents believe that Poles have a positive attitude towards disabled persons, but, according to $48 \%$, this attitude is negative. Two thirds of respondents (65\%) declare their readiness to provide unselfish neighbourly help to a disabled person, but only $6 \%$ say that they already participate in such help. Unfortunately, every fifth (20\%) respondent would not like to take part in this kind of initiative. It must be stressed that the declared readiness to provide help depends on the type of disability - Poles are least willing to help persons with mental diseases (Chard, 2007: 3).

Similar studies carried out in 2017 show that the percentage of persons declaring their acquaintance and contacts with disabled persons has risen during the decade; in the opinion of $7 \%$ of respondents, such persons can count on neighbourly support. However, among persons who have had disabled persons in their family or among their friends, the percentage share of declarations of neighbourly help and support increases to $24 \%$. Such a willingness is expressed by $73 \%$ of respondents, and 5\% actually provide help (Omyłka-Rudzka, 2017: 5-7).

Interesting data have been obtained from studies conducted by Witold Janocha, who concludes that neighbourly help and support granted to disabled persons and their families are insufficient. 'Neighbours are most active in providing information about the possibilities of obtaining additional help; this was indicated by $3 \%$ of respondents. Mental support was also indicated by less than $3 \%$ of respondents. In other cases, there are $1 \%-2 \%$ of indications, and only $0.5 \%$ of neighbours offered spiritual help and understanding of the sense of suffering (Janocha, 2009: 121). Examining the opinions of disabled persons, the author also stated that although more extensive neighbourly help could be expected particularly in villages and small towns, only $5 \%$ of respondents mentioned any of their neighbours among those who spend a significant amount of time taking care of a disabled person in some way. It is also worth noting that none of over 700 respondents place neighbours first; fewer than $1 \%$ put them in second place and slightly more than $4 \%$ put them in third place. Thus, although neighbourly help is present, it occurs sporadically (Janocha, 2009: 186).

Analysing the results obtained in studies on opinions of the local environment about disabled persons, Paweł Boryszewski (2007) says that respondents 'having disabled persons among their family members and neighbours and keeping in 
touch with the disabled ... indicated neighbours much more often as persons providing support, but this category of answer was chosen least frequently in general. This may suggest that not only able-bodied persons without contact with disabled environments are closed, but also disabled persons themselves and their families, caretakers and other collaborators do not see too many possibilities for neighbourly support' (Boryszewski, 2007: 39). It transpires that neighbourly co-operation and help remains the area that is used to a relatively small extent.

Interesting conclusions from research on attitudes towards disabled persons in the field of neighbourly relations are formulated by Paweł Stankiewicz. He states that 'a majority of respondents declare that they would have a friendly attitude to a new neighbour on a wheelchair: $21.74 \%$ would be definitely satisfied and $30.43 \%$ would rather be satisfied with their new neighbour, which accounts for more than one half. Interestingly, nobody would be dissatisfied: the remaining part of the respondents have no opinion about their new neighbour (47.3\%) (...) Over 75\% of respondents expressed the will to provide aid to a disabled neighbour' (Stankiewicz, 2008: 6).

The aforementioned examples show that, in spite of relatively high rates of society's declarations concerning positive attitudes to disabled persons and their families, declarations of readiness to establish closer neighbourly relations with them become relatively less frequent. The actual maintenance of closer neighbourly contacts and the actual provision of help and support is even more limited, being almost always connected with the declaration of family and neighbourly relations and other contacts with the disabled. This fact has already been reported earlier.

On the occasion of these reflections, it seems necessary to indicate another aspect of the presence of the problem of disability in the neighbourhood. The aforementioned media reports raise huge concerns. For example, as we can read in Express Bydgoski, neighbours did not agree to the liquidation of an architectural barrier on one of the urban housing estates. 'Unfortunately, the woman fell ill. Her health did not allow her to go up the stairs located at the entrance to the building on her own. Therefore, the woman and her husband made efforts to obtain money and permission to build a lift or a ramp. Sadly, not all of the residents expressed consent to this kind of investment, and because of the lack of good will, the woman has become trapped in her own apartment' (Walenczykowska, 2017). In another case (in a medium-sized city), a housing association deprived a mother bringing up a disabled daughter on her own of the right to use a parking place (at the request of her neighbours). The embittered mother says: 'Sometimes I park two blocks farther due to the lack of space. My daughter is seven years' old; she does 
not walk and weighs around $20 \mathrm{~kg}$. I don't understand how people who do not know my situation could make such a decision' (TVN 24 Pomorze, 2014).

Unfortunately, such situations and similar ones occur quite frequently, although they should never happen. Thus, it turns out that neighbourhood is not always kind and friendly to a disabled person and her/his family, which contradicts social declarations of positive social attitude.

\section{Concluding remarks}

As Katarzyna Segiet emphasises, at present, in every area of human social life, 'intense changes related to globalisation and political-social transformation processes are visible. Apart from progress, they often reveal their unintentional results. They reveal various aspects of human functioning in countless spheres of life, on many levels of organisation, and they indicate previously unknown phenomena and processes occurring in them.' (Segiet, 2015: 35).

As an attempt to show one aspect of the consequences of modern changes in the space of social life, the above reflections allow us to conclude that a family with a disabled person experiences both positive and negative attitudes and behaviours of their neighbours. Disability in itself is always a difficult situation for the individual and his/her family. It is very important for the family not to remain alone with the problem of disability, because it is difficult to handle this situation without a support network. As an integral competent of the life environment of every human being, the neighbourhood has an important task to fulfil. Moreover, it is not a question of any great deeds, but of ordinary human sensitivity and kindness towards the other person and a neighbour who simply deserves this, regardless of his disability.

\section{Bibliography}

Boryszewski P. (2007), Niepełnosprawni w opinii społeczności lokalnych na przykładzie 10 wybranych gmin $w$ Polsce, Warszawa.

CBOS (2007), Postawy wobec osób niepetnosprawnych. Komunikat $z$ badań CBOS, https://www.cbos. pl/SPISKOM.POL/2007/K_169_07.PDF, accessed: 15.11.2018.

CBOS (2017), Polacy o relacjach $z$ sąsiadami. Raport CBOS, https://wiadomosci.radiozet.pl/Polska/ CBOS-Polacy-o-relacjach-z-sasiadami-poprawne-ale-niezbyt-bliskie, accessed: 15.12.2018.

Chajda E. (2007), Postawy wobec niepelnosprawnych. Komunikat z badań, Warszawa.

Czarnecki P. (2012), Pedagogika społeczna. Podstawowe pojęcia i definicje, Społeczeństwo i Edukacja. Międzynarodowe Studia Humanistyczne, no. 1. 
Górnicka B. (2012), Niepełnosprawność w życiu jednostki, rodziny i społeczeństwa, [in:] B. Górnicka, A. Kurcz (eds.), Pedagogiczne refleksje. Księga jubileuszowa dedykowana Profesor Józefie Bragiel, Opole.

Janocha W. (2009), Rodzina z osobq niepetnosprawna w społecznym systemie wsparcia, Kielce.

Kazanowski Z. (2015), Społeczny wymiar współczesnej koncepcji niepełnosprawności intelektualnej, Annales Universitatis Mariae Curie-Skłodowska. Sectio J, vol. XXVIII, 1.

Kirenko J. (2007), Indywidualna i społeczna percepcja niepełnosprawności, Lublin.

Morizon (2017), Badanie relacji sasiedzkich. Raport Morizon, http://www.morizon.pl/blog/jakimi-sasiadami-sa-polacy-raport/, accessed: 15.12.2018.

Omyła-Rudzka M. (2017), Niepetnosprawni wśród nas. Komunikat $z$ badań, Warszawa.

Pilch T., Lepalczyk I. (eds.) (1995), Pedagogika społeczna. Człowiek w zmieniającym się świecie, Warszawa.

Segiet K. (2015), Rodzina jako przestrzeń życia (dla) współczesnej młodzieży, [in:] K. Segiet (ed.), Młodzież $w$ dobie przemian społeczno-kulturowych, Poznań.

Stankiewicz P. (2008), Raport z badania postaw wobec osób niepełnosprawnych, Warszawa.

Szczurek-Boruta A. (2016), Lokalne środowisko życia i kształtowanie tożsamości otwartej w perspektywie edukacji międzykulturowej, Pedagogika Społeczna, no. 3(61).

Theiss W. (2001), Mała ojczyzna: perspektywa edukacyjna-utylitarna, [in:] W. Theiss (ed.), Mała ojczyzna. Kultura. Edukacja. Rozwój lokalny, Warszawa.

TVN 24 Pomorze (2014), Matka $z$ niepełnosprawnym dzieckiem straciła miejsce parkingowe. „Tak chcieli sąsiedzi”, https://www.tvn24.pl/pomorze,42/matka-z-niepelnosprawnym-dzieckiem-stracila-miejsce-parkingowe-tak-chcie li-sasiedzi,395724.html, accessed: 10.12.2018.

Walenczykowska H. (2017), Więźniowie sąsiadów. Tak traktuje się niepełnosprawnych, Ekspres Bydgoski, 18 February, https://expressbydgoski.pl/wiezniowie-sasiadow-tak-traktuje-sie-niepelnosprawnych/ar/c3-11805259/2, accessed: 10.12.2018.

Żuraw H. (2016), Ewolucja podejścia do niepełnosprawności w kulturze Zachodu - perspektywa antropologii, Pogranicze. Studia społeczne, vol. XXVIII. 